\title{
The dangerous, careless folly of biodiversity loss
}

\author{
Zakri Abdul Hamid
}

\begin{abstract}
The accelerating disappearance of the Earth's wild plants and animals constitutes a fundamental threat to the wellbeing and even the survival of humankind. Biodiversity from terrestrial, marine, coastal and inland water ecosystems provides the basis for ecosystems and the services they provide that underpin human wellbeing. However, biodiversity and ecosystem services are declining at an unprecedented rate, and in order to address this challenge, adequate local, national and international policies need to be adopted and implemented. To achieve this, decision-makers need scientifically credible and independent information that takes into account the complex relationships between biodiversity, ecosystem services and people. They also need effective methods to interpret this scientific information in order to make informed decisions. The scientific community must understand the needs of decision-makers better in order to provide them with the relevant information. In essence, the dialogue between the scientific community, governments and other stakeholders on biodiversity and ecosystem services needs to be strengthened. To this end, a new platform has been established by the international community - the 'Intergovernmental Platform on Biodiversity and Ecosystem Services' (IPBES). IPBES was established in April 2012, as an independent intergovernmental body open to all member countries of the United Nations. The members are committed to building IPBES as the leading intergovernmental body for assessing the state of the planet's biodiversity, I am honoured to be the Founding Chair of the organisation. In the article that follows I have outlined my perception of the background to the problem and of the way forward ecosystems and the essential services they provide to society.
\end{abstract}

Keywords: Intergovernmental science-policy platform, Biodiversity, Ecosystem services, Sustainable development

\section{Background}

Scientists are warning us in ever louder terms that the loss of plant and animal species on Earth - both wild and domesticated - constitutes a fundamental threat to the wellbeing and even the survival of humankind [1]. Most indicators of the state of biodiversity (covering species' population trends, extinction risk, habitat extent and condition, and community composition) showed declines, with no significant recent reductions in rate, whereas indicators of pressures on biodiversity (including resource consumption, invasive alien species, nitrogen pollution, overexploitation and climate change impacts) showed increases [2].

Even though the science of what is happening to our biodiversity and our climate is getting clearer, and the means to mitigate these problems in various sectors are being developed, the political challenges surrounding

Correspondence: zakri@pmo.gov.my

Prime Minister's Office, Level 3, West Wing, Perdana Putra Building, Federal Government Administrative Centre, Putrajaya 62502, Malaysia global change are far from being resolved. Therefore, it is pertinent that in order to develop sound policy requires sound science.

It has been clear for some time that a credible, permanent science policy platform for biodiversity and ecosystem services, modelled on the Intergovernmental Panel on Climate Change (IPPC), is an important but missing element in the international response to the biodiversity crisis. Thus the launch in January of the United Nations' new Intergovernmental Science-Policy Platform on Biodiversity and Ecosystem Services (ipbes.net) was widely welcomed. The new organisation has been created to narrow the gulf between leading international biodiversity scientists and national policy-makers.

\section{Main text}

The Millennium Ecosystem Assessment (MEA), which the distinguished UK scientist Robert Watson and I co-chaired eight years ago, demonstrated that an intergovernmental platform can create a clear, valuable policy-relevant 
consensus from a wide range of information sources about the state, trends and outlooks of human-environment interactions, with focus on the impacts of ecosystem change on human wellbeing. It showed that such a platform can support decision-makers in the translation of knowledge into policy. The MEA provides our baseline. The IPBES will tell us how much we have achieved, where we are on track, where we are not, why and options for moving forward. It will help to build public support and identify priorities.

While the structure of IPBES mimics that of the Nobel Prize-winning IPCC, its aims go further and includes capacity building to help bridge different knowledge systems. IPBES will respond to requests for scientific information related to biodiversity and ecosystem services from Governments, relevant multilateral environmental agreements and United Nations bodies, as well as other relevant stakeholders. While there are other organisations and initiatives that contribute to the science-policy interface on biodiversity and ecosystem services, IPBES is unique in that it serves as a global mechanism that is recognised by both the scientific and policy communities.

Some scientists warn that we may be in the 'sixth great extinction episode' in Earth's history, noting that the loss of biodiversity is happening faster and everywhere - even among farm animals [1].

Late last year, the UN Food and Agriculture Organisation declared that genetic diversity among livestock is declining, citing data that classify $22 \%$ of domesticated breeds at risk of extinction [3]. Breeds become rare because their characteristics either do not suit contemporary demand or because differences in their qualities have not been recognised - in short, a lack of appreciation of the value of indigenous breeds and their importance in niche adaptation as the environment changes. Industrialised countries, in particular, have demonstrated this failure of understanding through incentives to raise more uniform, product-focused breeds.

Among crops, meanwhile, about $75 \%$ of genetic diversity was lost in the last century as farmers worldwide switched to genetically uniform, high-yielding varieties and abandoned multiple local varieties. Indeed, we have identified some 30,000 edible plant species but only 30 crops account for $95 \%$ of human food energy, the bulk of which $(60 \%)$ comes down to rice, wheat, maize, millet and sorghum [3]. The decline in the diversity of crops and animals is occurring in tandem with the need to sharply increase world food production and as the environment changes [4], it is more important than ever to have a large genetic pool to enable organisms to withstand and adapt to new conditions. Our actions have been short-sighted indeed.

\section{Conclusion}

There are no simple blueprints for addressing a challenge as vast and complex as this but I believe it is imperative we commit to meeting the fundamental challenge of decoupling economic growth from natural resource consumption, which is forecast to triple by 2050 unless humanity can find effective ways to 'do more and better with less'.

We also need measures of societal progress that go beyond gross domestic product (GDP). We need the kind of vision embodied in the Inclusive Wealth Index being pioneered by Sir Partha Dasgupta of Cambridge University, Malaysian Anantha Duraiappah at the International Human Dimension Programme on Global Environmental Change in Bonn, and Pushpam Kumar at the UN Environment Programme. As they have convincingly argued, the enlightened measure of wealth and a real portrait of sustainable development include natural capital, not just output like GDP [5]. The idea that natural capital should be measured in this way makes many nervous. And I agree that many of the services the environment provides, like clean water and air, are irreplaceable necessities. In theory, the value of these natural treasures should be reflected in the price charged for their use. In practice, natural assets are hard to price well, if at all. And, while this work is still in its infancy, it is worth recalling that GDP has only been measured for the last 70 years and it, originally, was a far cruder metric than it is today.

The need to protect biodiversity features prominently in the recently proposed 'Sustainable Development Goals' [6], new multi-year global objectives to succeed the Millennium Development Goals (2000 to 2015). Specific targets, however, have yet to be defined, a process in which scientists must play a vocal role. For guidance, we have at hand the Aichi Biodiversity Targets, established through the Convention on Biological Diversity and internationally agreed for achievement by 2020 [7]. And the number one target is greater public awareness of the fundamental importance and value of ecosystem services and the selfinterested steps people can take to conserve biodiversity.

UNEP executive director Achim Steiner recently summed it up well [8]: 'When you run out of water, when you run out of arable land... and your rivers run dry, when your lakes silt up, when your fisheries collapse, then it is often too late to start talking about the value of biodiversity ecosystems. The cost of inaction is something that people have only just begun to appreciate.'

\section{Competing interests}

The author is the Founding Chair of the Intergovernmental Science-Policy Platform on Biodiversity and Ecosystem Services (IPBES) and Science Advisor to the Prime Minister of Malaysia.

Received: 8 July 2013 Accepted: 19 November 2013

Published: 5 December 2013

\section{References}

1. Loss of agricultural diversity: pressure state response indicators. [http:/www.fao.org/ag/againfo/programmes/en/lead/toolbox/Indust/ LossAgEA.htm\#Pressure] 
2. Butchart SH, Walpole M, Collen B, Van Strien A, Scharlemann JP, Almond RE, Bailie JE, Bomhard B, Brown C, Bruno J, Carpenter KE, Carr GM, Chanson J, Chenery AM, Csirke J, Davidson NC, Dentener F, Foster M, Galli A, Galloway JN, Genovesi P, Gregory RD, Hockings M, Kapos V, Lamarque JF, Leverington F, Loh J, McGeoch MA, McRae L, Minasyan A, et al: Global biodiversity: indicators of recent declines. Science 2010, 328:1164-116.

3. Progress made in stopping decline of livestock genetic diversity. [http://www.fao.org/news/story/jp/item/162972/icode/]

4. How to feed the world in 2050. [http://www.fao.org/fileadmin/templates/ wsfs/docs/expert_paper/How_to_Feed_the_World_in_2050.pdf]

5. UNU-IHDP and UNEP: Inclusive Wealth Report 2012, Measuring Progress Toward Sustainability. Cambridge: Cambridge University Press; 2012.

6. Sustainable development goals. [http://sustainabledevelopment.un.org/ index.php?menu=1300]

7. Aichi biodiversity targets. [http://www.cbdint/sp/targets/]

8. Roux M: Hundreds of plants and animals added to 'threatened' list. [http://www.google.com/hostednews/afp/article/ALegM5hTjhjC_LekjfGon_ vSzwdgpd3Xzw?docld=CNG.974ce35d4d614fa4951fda428ce50ddf.691]

doi:10.1186/2048-7010-2-16

Cite this article as: Hamid: The dangerous, careless folly of biodiversity loss. Agriculture \& Food Security 2013 2:16.

\section{Submit your next manuscript to BioMed Central and take full advantage of:}

- Convenient online submission

- Thorough peer review

- No space constraints or color figure charges

- Immediate publication on acceptance

- Inclusion in PubMed, CAS, Scopus and Google Scholar

- Research which is freely available for redistribution 